in renal function in the other six was progression of the intrinsic renal disease. Increase in dosage was commonly required to maintain a hypotensive effect. The indications for antihypertensive therapy in chronic renal disease are considered and it is suggested that methyldopa is at present the drug of choice for this purpose.

\section{Addendum}

Since this paper was written all the patients on long-term follow-up have been observed for a further six months, except 5 and 9, who died after three months with progressive renal failure. Of the 12 patients remaining on methyldopa, bloodpressure control has remained adequate in 11 ; a slight increase in dosage has been necessary in 5 patients; control remained less good in Case 8 and methyldopa therapy was supplemented by $10 \mathrm{mg}$. guanethidine.

Malignant hypertension with virtual blindness developed in Case 13 three months ago, by which time the creatinine clearance had fallen to $20 \mathrm{ml} . / \mathrm{min}$.; the patient now agreed to methyldopa therapy, and satisfactory control of blood-pressure with marked visual improvement was achieved and has been maintained without detectable deterioration in renal function.

Renal function has been maintained or improved in 9 of the original 12 patients remaining on methyldopa; the fall in the other three is slight (Case 8 , creatinine clearance 46 to 41 $\mathrm{ml} . / \mathrm{min}$.; Case 11,13 to $11 \mathrm{ml} . / \mathrm{min}$.; Case 14,30 to 27 $\mathrm{ml} . / \mathrm{min}$.); and there has been no further deterioration in renal function in Case 4, who had malignant hypertension.

One other side-effect of treatment was intermittent nocturnal diarrhoea, responding to symptomatic measures, in Cases 4 and 11. Fluid retention, responding to a thiazide diuretic, occurred in Cases 11 and 13.

We have also treated a further 10 patients with hypertension secondary to chronic renal disease for periods of one to six months ; satisfactory control of blood-pressure without deterioration in renal function has been achieved in seven, including one patient with malignant hypertension.

We are grateful to Professor E. M. McGirr for encouragement throughout this study, and to Miss Mary J. B. Gray, who performed the estimations of creatinine clearance.

\section{REFERENCES}

Bayliss, R. I. S., and Harvey-Smith, E. A. (1962). Lancet, 1, 763.

Brod, J. (1956). Ibid., 1, 973.

Daley, D., and Evans, B. (1962). Brit. med. F., 2, 156.

Dollery, C. T., and Harington, M. (1962). Lancet, 1, 759.

Ellis, A. (1942). Ibid., 1, 34.

Hamilton, M., and Kopelman, H. (1963). Brit. med. F., 1, 151

Hare, R. S. (1950). Proc. Soc. exp. Biol. (N.Y.), 74, 148.

Irvine, R. O. H., O'Brien, K. P., and North, J. D. K. (1962). Lancet, 1, 300.

Moyer, J. H., Handley, C. A., and Huggins, R. A. (1951). ¥. Pharmacol. exp. Ther., 103, 368.

Onesti, G., Brest, A. N., Novack, P., and Moyer, J. H. (1962). Amer. F. Cardiol., 9, 863.

Volhard, F. (1931). In Handbuch der inneren Medizin, edited by G. V. Bergmann and R. Staehelin, 2nd ed., vol. 6, Pt. 2, p. 1426. Springer, Berlin.

Wilson, C. (1953). Lancet, 2, 632.

- and Abrahams, D. G. (1957). Brit. med. Bull., 13, 39.

\title{
Hypoanabolic Hypoalbuminaemia in Gastro-intestinal Disease
}

\author{
K. N. JEEJEEBHOY*, M.B., M.R.C.P., M.R.C.P.ED.
}

Brit. med. F., 1964, 1, 30-35

Hypoalbuminaemia in gastro-intestinal disease is commonly associated with gastro-intestinal protein loss (Citrin et al., 1957 ; Gordon, 1959 ; Schwartz and Jarnum, 1959 ; Holman et al., 1959; Steinfeld et al., 1960 ; London et al., 1961 ; Davidson et al., 1961 ; Jeejeebhoy and Coghill, 1961). Patients with gastro-intestinal disease who have hypoalbuminaemia, however, do not invariably have current gastro-intestinal protein loss, and recent studies have indicated that deficient albumin synthesis alone may be an important cause of hypoalbuminaemia in some patients (Jeejeebhoy, 1962 ; Jones, 1962).

This paper describes the clinical features and studies of protein metabolism in 19 patients in whom hypoalbuminaemia associated with gastro-intestinal disease was due to deficient albumin synthesis. The results of intestinal and hepatic function tests are also given.

Reduced albumin synthesis was the chief cause of chronic hypoalbuminaemia in patients who had had a partial gastrectomy. This was the situation also in some patients suffering from idiopathic steatorrhoea and pancreatic disease, and in patients after gastro-intestinal albumin loss in ulcerative colitis, constrictive pericarditis, and Crohn's disease. The effects of treatment are described.

- West Middlesex Hospital, Isleworth, and Postgraduate Medical School of London. Present address: Atomic Energy Establishment
Richardson and Cruddas Building, Byculla, Bombay 8, India.
Serum Protein Estimation.-Total protein was estimated by the biuret reaction (Weichselbaum, 1946), using an autoanalyser as described in the Autoanalyser Technical Bulletin. Serum albumin was estimated by the HABA (2-[4'-hydroxybenzeneazo] -benzoic acid) dye method (Rutstein et al., 1954), using an autoanalyser calibrated against known standards of crystalline human albumin. Serum globulin was obtained by subtracting the value for serum albumin from that of the total serum protein. Electrophoresis of serum protein was performed on cellulose acetate and the strips were stained with Ponceau red.

Albumin turnover studies were carried out using the method described previously (Jeejeebhoy and Coghill, 1961 ; Jeejeebhoy, 1962). Radioiodinated human serum albumin (R.I.H.S.A.) was prepared by the method of McFarlane (1958). The patients were given Lugol's iodine and "amberlite IRA-400 (a)" by mouth for two days beforehand and throughout the period of observation. R.I.H.S.A. was injected intravenously and blood was taken into heparin 10 minutes after the injection and daily for between 7 and 14 days. Daily 24-hour urine and three-day stool collections were made.

Total exchangeable albumin (T.E.A.) is the body albumin, vascular and extravascular, in which the tracer is distributed. The value for the T.E.A. is obtained by adding the intravascular 
albumin to that in the two extravascular pools calculated by mathematical analysis (Matthews, 1957).

Gastro-intestinal (Exogenous) Catabolism of Albumin.R.I.H.S.A. excreted into the lumen of the bowel is rapidly digested, but the administration of amberlite prevents reabsorption of these digested products, as they are bound by the resin and thus excreted in the faeces. By measurement of faecal radioactivity and simultaneous reference to plasma activity the amount of albumin excreted into the gastro-intestinal tract is measured (Jeejeebhoy, 1962).

Endogenous catabolism, is the degradation of albumin which occurs in areas other than the lumen of the gastro-intestinal tract. The degradation products of R.I.H.S.A. catabolized at these sites are excreted in the urine. From measurement of urinary radioactivity the magnitude of this catabolism is determined, and the amount of albumin broken down in this way per day is calculated by reference to the total intravascular albumin.

Estimation of albumin synthesis was made by a method described by Matthews (1961). The principle of the method is that alteration in the specific activity of the plasma after an intravenous injection of R.I.H.S.A. can only be through an influx of unlabelled albumin into the circulation. This influx occurs both through synthesis $\left(\mathrm{K}_{01}\right)$ and by net transfer $\left(K_{T}\right)$ from the extravascular to the intravascular albumin compartment. Therefore by measurement of changes in the plasma specific activity the synthesis + net transfer $\left(\mathrm{K}_{01}+\mathrm{K}_{\mathrm{r}}\right)$ can be calculated. In a state of equilibrium $\mathrm{K}_{\mathrm{r}}$ and so $K_{01}+K_{T}$ would equal the true rate of albumin synthesis. However, if equilibrium did not exist there would be a net transfer of protein from the extravascular compartment, acting as reserve of serum albumin. The net transfer would result in $\mathrm{K}_{\mathrm{T}}$ having a finite value, and the true synthesis rate under these circumstances would be lower than the calculated synthesis. Nevertheless, whether or not there was a state of equilibrium the demonstration of a lowered rate of albumin synthesis by this method would be valid, because in the absence of equilibrium the calculated synthesis rate would be higher than the true synthesis.

Intestinal Function.-The patients were put on a 100-g. fat and a 100-g. protein diet, and faecal fat and nitrogen estimations were carried out. The methods used to undertake these estimations were the faecal fat excretion, estimated by a modification of the technique of van de Kamer et al. (1949), and the faecal nitrogen estimation, performed by a semi-microkjeldahl method of Fawcett (1954).

Liver-function Tests.--Serum bilirubin was estimated by a modified method of Gray and Whidbourne (1946). Serum cholesterol was estimated by a modified method of Bloor (1928). Alkaline phosphatase was estimated in an autoanalyser by the method of Kind and King (1954). Thymol turbidity was determined by the method of Maclagan (1944) and zinc turbidity by the method of Kunkel (1947). Serum transaminase was estimated by a method described in Sigma Technical Bulletin and expressed in Sigma Frankel units.

\section{Material}

Control Subjects.-Estimation was made of the albumin metabolism of three normal volunteers, three convalescent cases of myocardial infarction, one patient with a brain tumour, and one symptomless patient with carcinoma of the cervix four years after radiation therapy. Results of six of the control subjects have already been published (Jeejeebhoy, 1962).

Patients Studied.-Nineteen patients with hypoalbuminaemia associated with gastro-intestinal disease were studied. The clinical details are given in Table $\mathrm{I}$. There were six patients with partial gastrectomy and one with oesophago-gastrectomy. One patient had coeliac disease and three had adult idiopathic steatorrhoea. Two patients had pancreatic disease (pancreatic abscess and chronic pancreatitis) and three ulcerative colitis. There was one patient with Whipple's disease, one who had had a pericardiectomy for constrictive pericarditis, and one who had had a resection of the terminal ileum for Crohn's disease which was no longer active.

TABLB I.-Patients with Hypoalbuminaemia

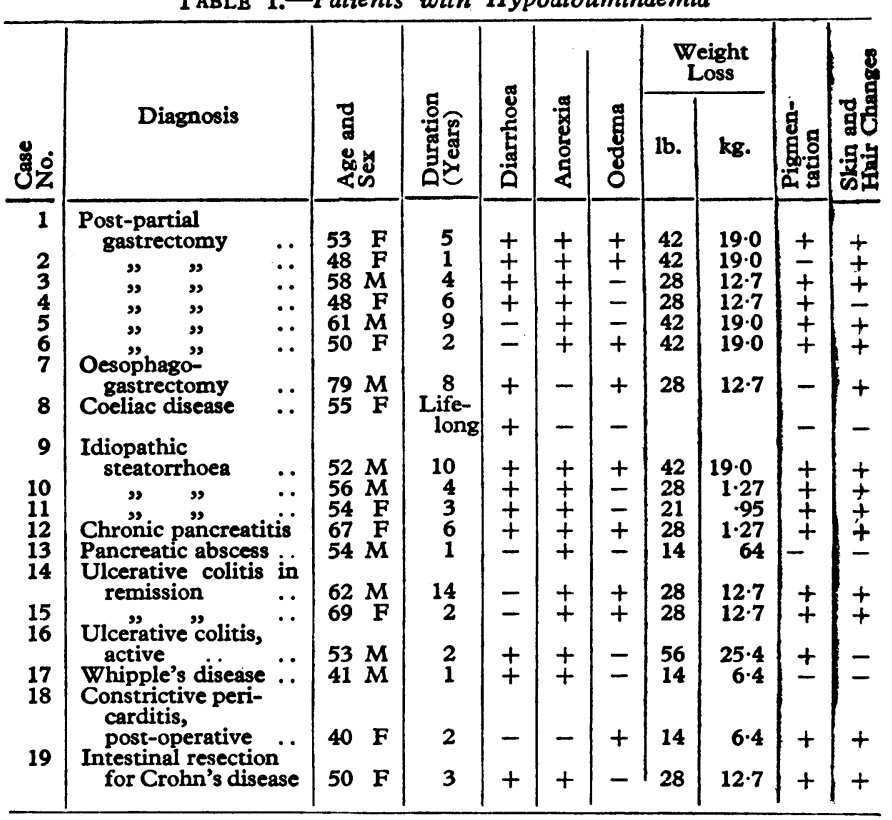

\section{Clinical Features}

All patients were aged 40 or over (Table I): four were aged $40-49,10$ were 50-59, four were $60-69$, and one was 79 .

Duration of Illness.-There was a long history of illness in most patients. Ten were ill for four years or longer. One patient (Case 13) had been feeling unwell for one year, but when found to have hypoalbuminaemia an acute pancreatic abscess was also discovered.

Anorexia was prominent in 16 patients, resulting in these patients eating small meals at infrequent intervals. Notable exceptions were one patient who had had gastrectomy (Case 7) and one with coeliac disease (Case 8), both of whom developed hypoalbuminaemia in spite of a good appetite.

Oedema was a presenting feature in only two patients (Cases 1 and 2). It was found on clinical examination in seven others. An interesting feature was the absence of oedema in 10 patients in spite of hypoalbuminaemia.

Loss of weight was found in all cases and ranged from 14 to $56 \mathrm{lb}$. (6.4 to $25.4 \mathrm{~kg}$.). In one patient (Case 8) it could not be assessed as she had suffered from coeliac disease since early infancy. She was dwarfed and weighed $38 \mathrm{~kg}$.

Asthenia was a prominent feature in all patients. They felt " off colour" and weak, and had "no energy." It was severe enough to interfere with work in 14 patients (Cases 1-4, 8-16, and 18).

Mental changes were observed in eight patients (Cases 1- 3 , $6,9,12,14$, and 19). Most patients were irritable, "difficult," and depressed. Two patients (Cases 6 and 14) had severe symptoms, which were the presenting complaints. One of these (Case 6) was hypomanic with depressive episodes and could not undertake intelligent conversation or direct her attention to a problem for any length of time. Case 14 had severe mental confusion and was incontinent on admission.

Skin and Hair Changes.-Pigmentation of the skin was present in 14 patients. There was no evidence of mucous membrane pigmentation. The skin looked wrinkled and 
atrophic in many of them, and this change was out of proportion to that expected for their age. Hair growth was also diminished in many of these patients.

Infection.-Eight patients (Cases 3, 5, 6, 7, 13, 14, 18, and 19) had evidence of infection; three had chronic bronchitis in acute exacerbation at the time of study (Cases 5, 7, and 14); one had osteomyelitis of the foot, secondary to ischaemia (Case 3) ; two (Cases 6 and 18) had tuberculosis; one (Case 13) had a pancreatic abscess; and one (Case 19) had multiple septic skin lesions.

Presenting Features. - Two patients presented with oedema (Cases 1 and 2). Nine presented with diarrhoea associated with their gastro-intestinal disease (Cases 3, 4, 8, 9, 10, 11, 16, 17, and 19). One patient (Case 15) had had diarrhoea in the past, but at the time of study her colitis was in remission, although she had hypoalbuminaemia. Two patients were admitted with acute bronchitis (Cases 5 and 7), one patient presented with abdominal pain (Case 12), and one with pyrexia of unknown origin (Case 13); in these four patients the hypoalbuminaemia was discovered on routine blood-protein estimations. Two patients (Cases 6 and 14) came with mental disturbance. One patient (Case 18) was investigated after follow-up studies had shown that hypoalbuminaemia was still present after successful pericardiectomy.

\section{Protein Metabolism}

Serum Proteins.-The serum protein levels are given in Table II. Total proteins were below the normal range in nine

\begin{tabular}{|c|c|c|c|c|}
\hline $\begin{array}{l}\text { Case } \\
\text { No. }\end{array}$ & $\begin{array}{c}\text { Total } \\
\text { Protein } \\
\text { (g. } / 100 \mathrm{ml} \text {.) }\end{array}$ & $\underset{\text { Sibumin }}{\text { Serum }}$ & $\underset{\text { Globulin }}{\text { Serum }}$ & $\begin{array}{l}\text { Electro- } \\
\text { phoretic } \\
\text { Pattern }\end{array}$ \\
\hline $\begin{array}{r}1 \\
2 \\
3 \\
4 \\
5 \\
6 \\
7 \\
8 \\
9 \\
10 \\
11 \\
12 \\
13 \\
14 \\
15 \\
16 \\
17 \\
18 \\
19\end{array}$ & $\begin{array}{l}4.6 \\
5.6 \\
6.4 \\
5.9 \\
6 \cdot 0 \\
5.4 \\
5.9 \\
6 \cdot 1 \\
7.2 \\
7.0 \\
7 \cdot 0 \\
5.1 \\
5.6 \\
6.4 \\
6.1 \\
4.9 \\
5.4 \\
6.4 \\
6.3\end{array}$ & $\begin{array}{l}2 \cdot 4 \\
2 \cdot 4 \\
2.9 \\
2 \cdot 5 \\
2 \cdot 5 \\
1.4 \\
2 \cdot 0 \\
2 \cdot 8 \\
1.9 \\
2 \cdot 9 \\
2 \cdot 8 \\
2 \cdot 0 \\
2 \cdot 3 \\
1 \cdot 6 \\
1.7 \\
0.9 \\
2 \cdot 2 \\
2.5 \\
2.8\end{array}$ & $\begin{array}{l}2 \cdot 2 \\
3 \cdot 2 \\
3 \cdot 5 \\
3 \cdot 4 \\
3 \cdot 5 \\
4 \cdot 0 \\
3 \cdot 9 \\
3 \cdot 3 \\
5 \cdot 3 \\
4 \cdot 1 \\
4 \cdot 2 \\
3 \cdot 1 \\
3 \cdot 2 \\
4 \cdot 8 \\
4 \cdot 4 \\
4 \cdot 0 \\
3 \cdot 2 \\
3 \cdot 9 \\
3 \cdot 5\end{array}$ & 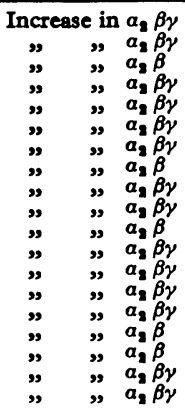 \\
\hline $\begin{array}{r}\begin{array}{c}\text { Range } \\
\text { Mean } \\
\text { Range } \\
\text { Mean }\end{array} \\
\text { Normal }\end{array}$ & $\begin{array}{c}4 \cdot 6-7 \cdot 2 \\
6 \cdot 1 \\
6 \cdot 0-8 \cdot 0 \\
7 \cdot 2\end{array}$ & $\begin{array}{c}0.9-3.0 \\
2.18 \\
3.5-5.9 \\
3.8\end{array}$ & $\begin{array}{c}2 \cdot 2-5 \cdot 3 \\
3 \cdot 65 \\
1 \cdot 83-3 \cdot 0 \\
2 \cdot 5\end{array}$ & \\
\hline
\end{tabular}

\begin{tabular}{|c|c|c|c|c|c|c|}
\hline $\begin{array}{l}\text { Case } \\
\text { No. }\end{array}$ & $\begin{array}{c}\text { Serum } \\
\text { Albumin } \\
\text { (g.l } \\
100 \mathrm{ml} .)\end{array}$ & $\begin{array}{l}\text { T.E.A. } \\
\text { (g./kg.) }\end{array}$ & $\begin{array}{c}\text { Total } \\
\text { Cata- } \\
\text { bolism } \\
\text { (mg. } / \mathrm{kg} . / \\
\text { day) }\end{array}$ & $\begin{array}{c}\text { Endo- } \\
\text { genous } \\
\text { Cata- } \\
\text { bolism } \\
\text { (mg./kg./ } \\
\text { day) }\end{array}$ & $\begin{array}{c}\text { Gastro- } \\
\text { intestinal } \\
\text { Catabolism }\end{array}$ & $\begin{array}{c}\text { Calcu- } \\
\text { lated } \\
\text { Synthesis } \\
\text { (mg./kg./ } \\
\text { day) }\end{array}$ \\
\hline $\begin{array}{r}1 \\
2 \\
3 \\
4 \\
5 \\
6 \\
7 \\
8 \\
9 \\
10 \\
11 \\
12 \\
13 \\
14 \\
15 \\
16 \\
17 \\
18 \\
19\end{array}$ & $\begin{array}{l}2 \cdot 4 \\
2.4 \\
2.9 \\
2.5 \\
2.5 \\
1.4 \\
2.0 \\
2.8 \\
1.9 \\
2.9 \\
2.8 \\
2.0 \\
2.3 \\
1.6 \\
1.7 \\
0.9 \\
2.2 \\
2.5 \\
2.8\end{array}$ & $\begin{array}{l}2.3 \\
2.3 \\
2.7 \\
2.0 \\
2.5 \\
1.4 \\
3.5 \\
2.8 \\
2.3 \\
3.4 \\
3.2 \\
1.9 \\
1.8 \\
1.6 \\
1.3 \\
0.9 \\
1.6 \\
2.9 \\
2.5\end{array}$ & $\begin{array}{c}51 \\
102 \\
131 \\
80 \\
82 \\
58 \\
98 \\
133 \\
87 \\
130 \\
111 \\
91 \\
87 \\
100 \\
125 \\
95 \cdot 5 \\
122 \\
106 \\
114\end{array}$ & $\begin{array}{c}20 \\
64 \\
69 \\
54 \\
61 \\
45 \\
58 \\
80 \\
58 \\
104 \\
63 \\
74 \\
41 \\
72 \\
92 \\
7 \cdot 5 \\
87 \\
80 \\
67\end{array}$ & $\begin{array}{l}31 \\
38 \\
62 \\
26 \\
21 \\
13 \\
40 \\
53 \\
29 \\
26 \\
48 \\
16 \\
46 \\
28 \\
33 \\
88 \\
35 \\
26 \\
47\end{array}$ & $\begin{array}{r}50 \\
90 \\
131 \\
80 \\
96 \\
58 \\
112 \\
138 \\
90 \\
118 \\
110 \\
80 \\
80 \\
100 \\
110 \\
118 \\
123 \\
109 \\
123\end{array}$ \\
\hline $\begin{array}{l}\text { Range } \\
\text { Mean }\end{array}$ & $\begin{array}{c}0.9-3 \cdot 0 \\
2 \cdot 18\end{array}$ & $\begin{array}{c}0 \cdot 9-3 \cdot 4 \\
2 \cdot 1\end{array}$ & $\begin{array}{c}51-133 \\
97\end{array}$ & $\begin{array}{c}20-104 \\
64\end{array}$ & $\begin{array}{c}13-88 \\
36\end{array}$ & $\begin{array}{c}50-138 \\
97\end{array}$ \\
\hline $\begin{array}{l}\text { Control } \\
\left\{\begin{array}{l}\text { Range } \\
\text { Mean }\end{array}\right.\end{array}$ & $3 \cdot 5-4 \cdot 2$ & $\begin{array}{c}3 \cdot 8-5 \cdot 0 \\
4 \cdot 2\end{array}$ & $\begin{array}{c}144-298 \\
2 \cdot 8\end{array}$ & $\begin{array}{c}100-242 \\
176\end{array}$ & $\begin{array}{c}28-62 \\
47 \cdot 5\end{array}$ & $\begin{array}{c}149-281 \\
228\end{array}$ \\
\hline
\end{tabular}

patients and normal in the others. All patients had hypoalbuminaemia. Serum globulin was raised in all but one patient (Case 1). Electrophoresis on cellulose acetate indicated that the hyperglobulinaemia in most of the patients was due to an increase in $\alpha_{2} \beta+\gamma$ globulins. In six patients, however, it was due to $\alpha_{2}$ and $\beta$ globulins only.

Albumin Turnover.-The results of the albumin turnover studies are given in Table III. The results in eight control subjects are also included for comparison. The T.E.A. and total catabolism were low in all patients. The low total catabolism was mainly due to a low endogenous catabolism, as the gastro-intestinal catabolism was normal in 12 patients (Cases 1, 2, 3, 7, 8, 9, 11, 13, 14, 15, 17, and 19, and low only in six. One patient (Case 16) had an increased gastro-intestinal protein catabolism. Albumin synthesis $\left(\mathrm{K}_{01}+\mathrm{K}_{\mathrm{T}}\right)$ was low in all patients.

\section{Intestinal-function Tests}

Faecal fat and nitrogen excretion were measured in 17 patients and faecal fat excretion alone in one patient (Case 17). The results are given in Table IV.

TABLB IV.-Intestinal-function Tests. Faecal Fats and Nitrogen; Six-day Average

\begin{tabular}{|c|c|c|}
\hline Case No. & Faecal Fats (g./24 hr.) & Faecal Nitrogen (g./24 hr.) \\
\hline $\begin{array}{r}1 \\
2 \\
3 \\
4 \\
5 \\
6 \\
7 \\
8 \\
9 \\
10 \\
11 \\
12 \\
13 \\
14 \\
15 \\
16 \\
17 \\
18 \\
19\end{array}$ & \begin{tabular}{r|r|}
$28 \cdot 6$ \\
$91 \cdot 0$ \\
$12 \cdot 1$ \\
$10 \cdot 0$ \\
$5 \cdot 9$ \\
$11 \cdot 1$ \\
$8 \cdot 6$ \\
$3 \cdot 2$ \\
$8 \cdot 4$ \\
$4 \cdot 2$ \\
$18 \cdot 0$ \\
$14 \cdot 1$ \\
$5 \cdot 0$ \\
$3 \cdot 8$ \\
$6 \cdot 0$ \\
$9 \cdot 0$ \\
$10 \cdot 4$ \\
$4 \cdot 9$ \\
\end{tabular} & $\begin{aligned} 10 \cdot 4 \\
12 \cdot 0 \\
4 \cdot 4 \\
2 \cdot 8 \\
2 \cdot 1 \\
1 \cdot 8 \\
2 \cdot 5 \\
3 \cdot 5 \\
4 \cdot 2 \\
3 \cdot 2 \\
4 \cdot 4 \\
1 \cdot 6 \\
2 \cdot 0 \\
2 \cdot 0 \\
\frac{8 \cdot 5}{7.5} \\
3 \cdot 7 \\
7 \cdot 5\end{aligned}$ \\
\hline Normal* $\left\{\begin{array}{l}\text { Range } \\
\text { Mean }\end{array}\right.$ & $\begin{array}{c}1 \cdot 8-6 \cdot 7 \\
4 \cdot 1\end{array}$ & $\begin{array}{c}0.8-2.5 \\
1.7\end{array}$ \\
\hline
\end{tabular}

Post-gastrectomy.-Both faecal fat and faecal nitrogen excretion were increased in four patients, the faecal fat alone was increased in two others, and both faecal fat and faecal nitrogen were normal in one patient (Case 5).

Idiopathic Steatorrhoea.-There was an increase of both faecal fat and nitrogen in two patients, but in the other two (Cases 8 and 10) the faecal nitrogen alone was increased.

Pancreatic Disease.-One patient (Case 12) had steatorrhoea but no creatorrhoea, and in Case 13 the faecal fat and nitrogen were normal.

Ulcerative Colitis.- Neither of the two patients studied had steatorrhoea, but the patient with active ulcerative colitis (Case 16) had an increased faecal nitrogen.

Whipple's Disease (Case 17).- This patient had steatorrhoea ; faecal nitrogen was not studied.

Constrictive Pericarditis (Case 18).-Both faecal fat and nitrogen were increased.

Crohn's Disease and Intestinal Resection (Case 19).-This patient had no steatorrhoea but faecal nitrogen was increased.

\section{Liver-function Tests}

The results in 18 cases are shown in Table V. There was no elevation of serum bilirubin level in any of the patients. The serum alkaline phosphatase was elevated in two patients with idiopathic steatorrhoea (Cases 10 and 11). In Case 11 
the alkaline phosphatase was thought to be predominantly of hepatic origin by starch-gel electrophoretic studies (Dr. D. Moss). This was supported by the finding of a 5-nucleotidase level of 54 units (normal 3-15 units). The zinc turbidity was elevated in eight patients. The elevation in the zinc and thymol turbidity was associated with changes in the serum globulin. Bromsulphthalein retention was raised in three (Cases 1, 7, and 14) of the 11 patients studied (Cases $1,3,4,6,7,8,9,10,14$,

TABLE V.-Liver-function Tests

\begin{tabular}{|c|c|c|c|c|c|c|}
\hline $\begin{array}{l}\text { Case } \\
\text { No. }\end{array}$ & $\begin{array}{c}\text { Bilirubin } \\
\text { (mg./ } \\
100 \mathrm{ml} .)\end{array}$ & $\begin{array}{c}\text { Cholesterol } \\
\text { (mg./ } \\
100 \mathrm{ml} .)\end{array}$ & $\begin{array}{c}\text { Alk. } \\
\text { Phos- } \\
\text { phatase } \\
\text { (K.-A. } \\
\text { Units) }\end{array}$ & $\begin{array}{l}\text { Thymol } \\
\text { Turbidity } \\
\text { (Units) }\end{array}$ & $\underset{\text { (Units) }}{\text { Zinc }}$ & $\begin{array}{c}\text { S.G.P.T. } \\
\text { Units) }\end{array}$ \\
\hline $\begin{array}{r}1 \\
2 \\
3 \\
4 \\
5 \\
6 \\
7 \\
8 \\
9 \\
10 \\
11 \\
12 \\
13 \\
14 \\
15 \\
16 \\
17 \\
19\end{array}$ & $\begin{array}{l}0.4 \\
0.5 \\
0.5 \\
0.5 \\
0.5 \\
0.9 \\
0.5 \\
0.5 \\
0.5 \\
0.5 \\
0.5 \\
0.5 \\
0.5 \\
0.5 \\
0.5 \\
0.5 \\
0.1 \\
0.5\end{array}$ & $\begin{array}{l}180 \\
192 \\
200 \\
290 \\
385 \\
110 \\
160 \\
310 \\
280 \\
200 \\
255 \\
180 \\
200 \\
242 \\
220 \\
202 \\
230 \\
210\end{array}$ & $\begin{array}{c}8 \\
9 \\
13 \\
12 \\
9 \cdot 8 \\
15 \\
12 \\
11 \\
5 \\
22 \\
123 \\
5 \\
6 \cdot 5 \\
6 \\
12 \\
6 \cdot 3 \\
8 \cdot 3 \\
12\end{array}$ & $\begin{array}{l}4 \\
3 \\
1 \\
4 \\
1 \\
2 \\
4 \\
1 \\
4 \\
1 \\
5 \\
2 \\
3 \\
6 \\
1 \\
1 \\
3.5 \\
2\end{array}$ & $\begin{array}{r}4 \\
4 \\
10 \\
7 \\
5 \\
8 \\
10 \\
4 \\
12 \\
10 \\
10 \\
10 \\
4 \\
10 \\
5 \\
4 \cdot 1 \\
11 \cdot 1 \\
6\end{array}$ & $\begin{array}{l}13 \\
14 \\
23 \\
23 \\
19 \\
17 \\
9 \\
24 \\
19 \\
12 \\
60 \\
16 \\
25 \\
16 \\
34 \\
24 \\
\frac{31}{31}\end{array}$ \\
\hline Normal & Up to 1 & $150-265$ & $3-13$ & $0-4$ & $2-8$ & $U_{p}$ to 40 \\
\hline
\end{tabular}

17, and 19). Serum cholesterol was within the normal limits in 15 patients and was raised in four (Cases 4, 5, 8, and 9). A liver biopsy was carried out in eight patients. None had cirrhosis. In two (Cases 10 and 13) mild fatty change was observed, and in six (Cases 1, 4, 8, 14, 17, and 19) the histology was normal.

\section{High-protein Diet}

\section{Effect of Treatment}

Fourteen patients (Cases 1-8, 10, 12, 14, 15, 18, and 19) were given a diet containing $100 \mathrm{~g}$. of protein daily for at least a month. Of these patients, two (Cases 8 and 10) with idiopathic steatorrhoea were also given a gluten-free diet. The serum albumin rose to normal on the high-protein diet in six patients (Cases 3, 4, 5, 12,15, and 19). Albumin turnover studies were then repeated in five of these patients, the results being given in Table VI. These studies showed that there had been an increase in the rate of albumin synthesis in four patients. In the other seven (Cases 1, 2, 6, 7, 10, 14, and 18) there was no change in the serum albumin, and a repeat albumin turnover in one patient (Case 1, Table VI) showed no increase in the rate of albumin synthesis.

Clinical response to a high-protein diet in these six patients was associated with greater vigour and appetite, and with an increase in weight. One patient (Case 19) gradually lost her pigmentation, and hair growth recommenced after six months on the diet. In addition they all became more co-operative, less irritable, and free of depression. When the serum albumin level rose, two patients (Cases 12 and 15) lost their oedema.

TABLE VI.-Serum Albumin and Albumin Synthesis Rate Before and

\begin{tabular}{|c|c|c|c|c|}
\hline \multirow{2}{*}{$\begin{array}{l}\text { Case } \\
\text { No. }\end{array}$} & \multicolumn{2}{|c|}{$\begin{array}{l}\text { Serum Albumin } \\
(\mathrm{g} . / 100 \mathrm{ml} .)\end{array}$} & \multicolumn{2}{|c|}{$\begin{array}{l}\text { Synthesis Rate } \\
\text { (mg./kg./day) }\end{array}$} \\
\hline & Before & After & Before & After \\
\hline $\begin{array}{r}1 \\
3 \\
4 \\
5 \\
12 \\
15 \\
19\end{array}$ & $\begin{array}{l}2.4 \\
2.9 \\
2.5 \\
2.5 \\
2.0 \\
1.7 \\
2.8\end{array}$ & $\begin{array}{l}2.2 \\
3.8 \\
4.0 \\
3.5 \\
3.3 \\
3.2 \\
3.9\end{array}$ & $\begin{array}{r}50 \\
131 \\
80 \\
96 \\
80 \\
110 \\
123\end{array}$ & $\begin{array}{r}75 \\
190 \\
= \\
122 \\
196 \\
165\end{array}$ \\
\hline \multicolumn{5}{|c|}{ Effect of Gluten-free Diet } \\
\hline 9 & 1.9 & $4 \cdot 3$ & 90 & 245 \\
\hline
\end{tabular}

There was no clinical change in the eight patients in whom there was no rise of serum albumin.

\section{Gluten-free Diet}

One patient with idiopathic steatorrhoea (Case 9) was given a gluten-free diet. Six months later there was a rise in the serum albumin and in the rate of albumin synthesis (Table VII). Clinically this patient became free of oedema and gained 4 st. $(25.4 \mathrm{~kg}$.$) in weight. Skin pigmentation disappeared and hair$ started to grow again. He was no longer depressed or irritabie.

Two patients (Cases 8 and 10) were on a gluten-free diet when they developed hypoanabolic hypoalbuminaemia, but in both cases the gluten-free diet had failed to induce a complete remission.

\section{Infusion of Human Serum Albumin}

Five patients (Cases 1, 6, 10, 14, and 18) who had not responded to a high-protein diet were infused with $200 \mathrm{~g}$. of dried human serum albumin (Lister Laboratories), at the rate of $25 \mathrm{~g}$. on alternate days. In all of them there was an initial rise of serum albumin to normal. In Cases $1,6,14$, and 18 the serum albumin remained normal a month after the infusion, and albumin turnover performed at that time demonstrated an increase in albumin synthesis (Table VII). The serum albumin has subsequently remained normal in these patients for periods of observation varying from 2 to 10 months. In Case 10 the serum albumin gradually fell after infusion, and a further albumin turnover study performed one month after the infusion showed no change (Table VII). After albumin infusion the electrophoretic pattern of the serum proteins became normal, mainly through a reduction in globulin. An illustrative strip showing this change is given in the Chart.

TABLE VII.-Serum Albumin, and Albumin Synthesis Rate Before and

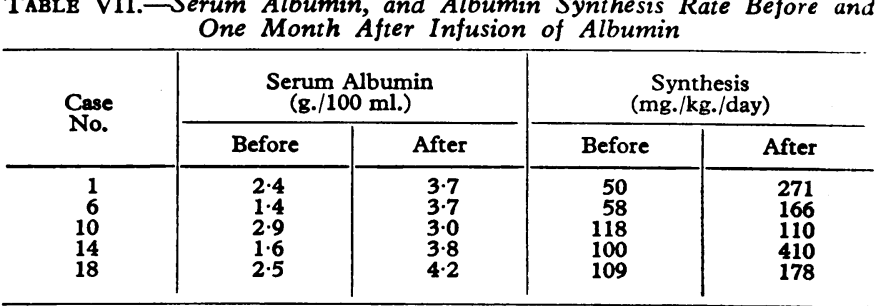

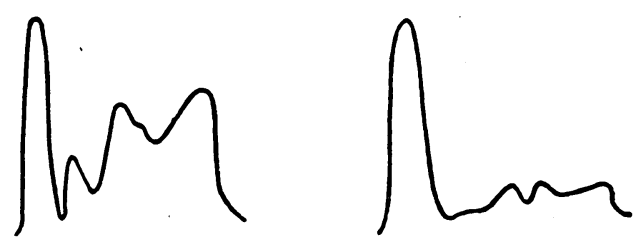

Serum electrophoretic pattern before and after albumin infusion.

Clinical improvement was often striking after albumin infusion. The two patients who presented with mental changes (Cases 6 and 14) were dramatically improved after the infusion. The patient (Case 14) who was mentally confused and incontinent on admission improved sufficiently to be able to luok after himself at home. The patient (Case 6) admitted in a hypomanic state became quite manageable, and developed insight into her condition after the infusion. Improved appetite and a gain in weight were noted in both these patients and in two others (Cases 1 and 10). The fifth patient (Case 18) initially had few symptoms associated with hypoalbuminaemia.

In two patients (Cases 6 and 14) there has subsequently been decrease of pigmentation and regrowth of hair.

The clinical improvement was temporary in the patient (Case 10 ) in whom the serum albumin fell after infusion. 


\section{Effect of Other Therapy}

The patient with a pancreatic abscess (Case 13) improved clinically after surgical drainage of the abscess and his albumin synthesis rose to $210 \mathrm{mg} . / \mathrm{kg}$. $/$ day, with a corresponding improvement in serum albumin, which increased to $3.9 \mathrm{~g} . /$ $100 \mathrm{ml}$. The patient with active ulcerative colitis (Case 16) improved markedly on 60 units of A.C.T.H. given daily for six weeks, after which he was again under study. His serum albumin rose from 0.9 to $3.6 \mathrm{~g} . / 100 \mathrm{ml}$., with a corresponding rise in albumin synthesis from 118 to $290 \mathrm{mg} . / \mathrm{kg} . /$ day. $\mathrm{He}$ was the only patient who showed evidence of loss of gastrointestinal protein: during steroid treatment it fell from 88 to $61 \mathrm{mg} . / \mathrm{kg}$./day.

\section{Discussion}

These results show that the low serum albumin levels in these patients were due to reduced synthesis. In contrast to patients with protein-losing enteropathy, only one of them had evidence of protein loss, and in this patient the loss was only slight.

Albumin Turnover Studies.-Measurement of synthesis (Matthews, 1961) showed that there was reduced albumin synthesis in all these patients. This method assumes that the patients were in equilibrium. Even if this had not been the case the method would have given a result which was greater than the true synthesis. Since the calculated synthesis in all these patients was below the control range it could be concluded that the true synthesis was low. As would be expected, the total catabolism was low - a reflection of the low T.E.A. in these patients (Jeejeebhoy, 1962).

Serum Protein Changes in Hypoanabolic Hypoalbuminaemia. In addition to hypoalbuminaemia there is usually an increased globulin level (Table II). In these patients it seemed to be related to the hypoalbuminaemia in some way, for the serum globulin returned to normal after albumin infusion; but this increase in serum globulin could also be due to infection in seven patients (Cases 3, 5, 6, 13,14, 18, and 19). These changes in globulin have also been observed in post-gastrectomy hypoalbuminaemia by Biserte and Guerrin (1954). They do not occur in patients who have gastro-intestinal protein loss (Waldmann et al., 1961) possibly because there may also be intestinal loss of globulin in such patients. In the absence of associated liver, renal, and neoplastic disease this difference in serum globulin levels between patients with hypercatabolic and hyperanabolic hypoalbuminaemia may be helpful in diagnosis.

\section{Aetiological Factors}

Three factors appear to be operative in the reduction of albumin synthesis: diet, absorption, and dysfunction of the l'ver. In most patients a combination of factors were operative.

Intake of Protein.-The intake of food in most of these patients was diminished owing to anorexia. Diet histories in two patients (Cases 5 and 6) revealed a protein intake of only 36 and $16 \mathrm{~g}$. respectively per day. However, three patients (Cases 7, 8, and 18) developed hypoalbuminaemia in spite of a good appetite and reasonable intake of food.

Role of Malabsorption.-Protein starvation may reduce albumin synthesis through a diminished availability of aminoacids. Furthermore, experimental protein malnutrition has been shown to cause a reduction in liver microsomes (Muntwyler et al., 1950; Wikramanayake et al., 1953), which are the only site of albumin synthesis. Thus protein malnutrition could reduce the albumin synthesis directly as well as through its effect on the liver. Furthermore, malabsorption of carbohydrates and fats would increase the utilization of amino-acids for energy production (Werner, 1948), and thus diminish the availability of nitrogen for protein synthesis. In the present series there was evidence of fat and/or nitrogen malabsorption in 14 patients. Weight loss, wrinkled inelastic skin, and psychological changes are all suggestive of chronic malnutrition (Davidson et al., 1959). Their presence in these patients was in keeping with nutritional deficiency. Lasting improvement on a high-protein diet or following albumin infusion in a proportion of patients suggested that, in them, malnutrition was the chief cause of hypoalbuminaemia.

Role of Liver Dysfunction.-It is now accepted that the liver is the only site of albumin synthesis, and liver dysfunction could be an important cause of impaired albumin production. In the present series most patients had normal biochemical parameters of liver function. However, there may have been liver dysfunction in two patients (Cases 10 and 11), as shown by elevated alkaline phosphatase without other evidence of bone disease, and three patients (Cases 1, 7, and 14) had an increased bromsulphthalein retention. However, histological changes were minimal in the patients studied. Infections are known to cause damage to the liver through bacterial toxins and fever (Bradley and Conan, 1947 ; Zimmerman and Thomas, 1950). A third of these patients had evidence of bacterial infection. In one patient (Case 13) its aetiological relation to the hypaalbuminaemia was seen when, after drainage of a pancreatic abscess, his serum albumin rose to normal levels without other treatment. In other cases it was not possible to assess the contribution of infection to the hypoalbuminaemic state, as antibiotics could not justifiably be withheld from these patients. In consequence the septic condition was treated concurrently with the administration of oral or parenteral protein therapy.

Role of Gastro-intestinal Protein Loss.-Current gastrointestinal protein loss was present in one patient only. However, past gastro-intestinal protein loss had been demonstrated in one patient (Case 18) prior to pericardiectomy. It had also probably been present in two others (Cases 14 and 15) when they had active ulcerative colitis with the passage of blood per rectum. A negative nitrogen balance is known to occur in patients with active ulcerative colitis (Welch et al., 1937). It is therefore likely that prolonged protein loss, from the lower end of the gastro-intestinal tract, would deplete the body of nitrogen and thus reduce albumin synthesis as observed in these three patients (Cases 14, 15, and 16).

\section{Clinical Features}

Age.-T. S. Freeman (personal communication, 1962) found that the rate of albumin synthesis tends to diminish with age in patients with the nephrotic syndrome. In the present series the patients were all aged 40 years or more, and this agegrouping contrasts with hypercatabolic patients who had a wide range of age incidence (Table VIII).

TABLE VIII.-Ten-year Age-group Distribution of 40 Patients with Hypercatabolic Hypoalbuminaemia

\begin{tabular}{l|c|c|c|c|c|c|c}
\hline Age-group & $<20$ & $20-$ & $30-$ & $40-$ & $50-$ & $60-$ & $70-$ \\
\hline
\end{tabular}

Physical State.-The physical features of these patients with wasting, skin and hair changes, and asthenia are all suggestive of total protein deficiency as seen in kwashiorkor. In contrast, patients with uncomplicated gastro-intestinal protein loss as seen in idiopathic hypoproteinaemia are physically well except for oedema. Skin and hair changes and asthenia have been observed in post-gastrectomy hypoalbuminaemia by Lambling (1952). Another interesting feature not observed in proteinlosing enteropathy was the absence of oedema in 10 patients with hypoanabolic hypoalbuminaemia. The absence of oedema did not depend upon the serum albumin level. For example, one patient (Case 16) had no oedema although his serum albumin was $0.9 \mathrm{~g} . / 100 \mathrm{ml}$.

Mental change was another feature not reported in proteinlosing enteropathy. It was present in just under half the 
patients. The direct relation of the mental state to the hypoalbuminaemia was demonstrated in two patients whose rather profound mental changes were reversed by albumin infusion.

Duration of Illness.-Post-gastrectomy hypoalbuminaemia has been observed to follow gastric surgery after the delay of many months (Lambling, 1952). In the present series this observation has been confirmed and extended to other patients with gastro-intestinal disease presenting with hypoanabolic hypoalbuminaemia. This latent period can be attributed to the operation of three factors: difficulty in diagnosis, as oedema is absent in many patients ; the utilization of extravascular stores of albumin to replenish circulating albumin; and the time required for malnutrition to produce a reduction in liver microsomes, which in turn would reduce albumin synthesis.

\section{Treatment}

The treatment of hypoanabolic hypoalbuminaemia consists in improving the nutrition of the patient and treating intercurrent infection or associated gastro-intestinal disease.

Diet.-The value of a high-protein diet is obvious in patients who have been subsisting on a deficient diet. Furthermore, in the presence of malabsorption, protein and calorie intake would have to be raised above normal to permit the absorption of optimal amounts of nutriment. Diet alone was successful in six patients (Cases 3, 4, 5, 12, 15, and 19), but failed in eight others (Cases 1, 2, 6, 7, 8, 10, 14, and 18). Of these, two (Cases 1 and 2) had very severe malabsorption, and three (Cases 6,7 , and 14) were very ill with gross emaciation and active pulmonary infection. These patients all subsequently responded to intravenous albumin therapy. Two patients with idiopathic steatorrhoea (Cases 8 and 10) had responded incompletely to a gluten-free diet: one (Case 8) still had severe diarrhoea, and the other failed to gain weight and developed recurrent irondeficient anaemia. In contrast the serum albumin of a patient (Case 9) who had adequately responded to a gluten-free diet became normal.

Albumin Infusion.-This was especially useful where a highprotein diet had failed in the presence of severe hypoalbuminaemia, and where mental changes were present. After infusion it was found necessary to continue a good diet to maintain a normal serum albumin level. The need for intravenous protein therapy before a normal serum albumin can be maintained by oral protein alone has been observed in post-gastrectomy hypoalbuminaemia (Lambling, 1952). One patient with idiopathic steatorrhoea (Case 10) did not respond adequately to an albumin infusion. He showed evidence of continued malabsorption, and previous albumin turnover studies indicated an intermittent gastro-intestinal albumin leak, possibly due partly to loss of blood, since he also had recurrent iron-deficient anaemia.

Hypoalbuminaemia in gastro-intestinal disease due to deficient albumin synthesis has hitherto received little attention. In a personally studied group of 59 patients with gastro-intestinal disease and hypoalbuminaemia, deficient albumin synthesis was found in the 19 reported in this paper.

This condition is best treated by measures designed to improve nutrition. In patients refractory to dietary therapy albumin infusions have a beneficial and lasting effect. Patients with continuing intestinal protein loss, as would be expected, do not benefit from albumin infusions.

\section{Summary}

Nineteen patients with evidence of low albumin synthesis were discovered in a group of 59 patients with hypoalbuminaemia and gastro-intestinal disease.

Gastrectomy, idiopathic steatorrhoea, pancreatic disease, and healed ulcerative colitis constituted the main clinical associations.
Unlike patients in whom there is dominant gastro-intestinal protein loss, there was an increase in serum globulin associated with the hypoalbuminaemia.

Diet histories and intestinal- and liver-function tests showed that poor intake, malabsorption, and hepatic dysfunction were factors present in those with deficient synthesis. Furthermone, infection which is known to depress liver function was found in some of these cases, and appeared to be the chief cause of hypoalbuminaemia in one case.

Clinically these patients were emaciated, had skin and hair changes, and in many instances were remarkably free from oedema in spite of a low serum albumin. Mental change wes also prominent in two patients. Many patients had associated infective conditions.

These cases could be treated successfully with a high-protein diet, albumin infusion, and antibiotics when necessary.

I am grateful to Dr. N. F. Coghill, of the West Middlesex Hospital, Isleworth, and to Dr. C. C. Booth, of the Postgraduate Medical School of London, for allowing these studies to be undertaken on Cases 3-16 and 19 and Cases 1 and 2 respectively. I am also grateful to them for helpful advice in preparing the text of this paper. I thank Dr. J. F. Goodwin, of the Postgraduate Medical School of London, for allowing me to study Case 18, and Dr. J. Stuart-Mason, consultant physician, London Hospital, for Case 17. I would also like to thank Dr. M. Lubran and his staff for having undertaken most of the biochemical estimations and for helpful technical advice. Thanks are also due to Dr. D. Moss, of the Postgraduate Medical School of London, for having undertaken alkaline phosphatase and 5-nucleotidase studies on Case 11. I would also like to thank Dr. A. K. Knudsen, of the West Middlesex Hospital, and Professor C. V. Harrison, of the Postgraduate Medical School of London, for having interpreted the liver biopsies.

\section{REFERENCES}

Biserte, G., and Guerrin, F. (1954). Arch. Mal. Appar. dig., 43, 876. Bloor, W. R. (1928). F. biol. Chem., 77, 53.

Bradley, S. E., and Conan, N. J. (1947). f. clin. Invest., 26, 1175.

Cirrin. Y., Sterling, K., and Halsted, J. A. (1957). New Engl. F. Med., 257, 906.

Davidson, J. D., Waldmann, T. A., Goodman, D. S., and Gordon, R. S. (1961). Lancet, 1, 899.

Davidson, L. S. P., Meikleiohn, A. P., and Passmore, R. (1959). Human Nutrition and Dietetics. Livingstone, Edinburgh.

Fawcett, J. K. (1954). f. med. Lab. Technol., 12, 12.

Gordon, R. S. (1959). Lancet, 1, 325.

Gray, C. H., and Whidbourne, J. (1946). Biochem. 7., 40, 81.

Holman, H., Nickel, W. F., jun., and Sleisenger, M. H. (1959). Amer. f. Med., 27, 963.

Jeejeebhoy, K. N. (1962). Lancet, 1, 343.

- and Coghill, N. F. (1961), Gut, 2, 123.

Jones, J. H. (1962). Lancet, 1, 892.

van de Kamer, J. H., Huinink, H. ten B., and Weyers, H. A. (1949). 7 biol. Chem., $177,347$.

Kind, P. R. N., and King, E. J. (1954). 7. clin. Path., 7, 324

Kunkel, H. G. (1947). Proc. Soc. exp. Biol. (N.Y.), 66, 217.

Lambling, A. (1952). Gaz. méd. port., 5, 49.

London, D. R., Bamforth, J., and Creamer, B. (1961). Lancet, 2, 18.

McFarlane, A. S. (1958). Nature (Lond.), 182, 53.

Maclagan, N. F. (1944). Brit. 7. exp. Path., 25, 15.

Matthews, C. M. E. (1957). Phys. in Med. Biol., 2, 36

- (1961). 7. clin. Invest., 40, 603.

Muntwyler, E. Seifter, S., and Harkness, D. M. (1950). F. biol. Chem., $184,181$.

Rutstein, D. D., Ingenito, E. F., and Reynolds, W. E. (1954). F. clin. Invest., 33, 211.

Schwartz, M., and Jarnum, S. (1959). Lancet, 1, 327.

Steinfeld, J. L., Davidson, J. D., Gordon, R. S., and Green, F. B. (1960). Amer. F. Med., 29, 405.

Waldmann, T. A., Steinfeld, J. L., Dutcher, T. F., Davidson, J. D., and Gordon, R. S. (1961). Gastroenterology, 41, 197.

Weichselbaum, T. E. (1946). Amer. 7. clin. Path., 16, 40.

Welch, C. S., Adams, M., and Wakefield, E. G. (1937). \%. clin. Invest., $16,161$.

Werner, S. C. (1948). Ibid., 27, 561.

Wikramanayake, T. W., Heagy, F. C., and Munro, H. N. (1953). Biochem. biophys. Acta (Amst.), 11, 566.

Wollaeger, E. E., Comfort, M. W., and Osterberg, A. E. (1947). Gastroenterology, 9, 272.

Zimmerman, H. J., and Thomas, L. J. (1950). f. Lab. clin. Med., 35, 556. 